\author{
Board of Governors of the Federal Reserve System \\ International Finance Discussion Papers \\ Number 485 \\ October 1994
}

Technological Progress and Endogenous Capital Depreciation: Evidence from the U.S. and Japan

Robert Dekle

Note: International Finance Discussion Papers are preliminary materialis circulated to stimulate discussion and critical comment. References in publications to International Finance Discussion Papers (other than an acknowledgment that the writer has had access to unpublished material) should be cleared with the author or authors. 


\section{ABSTRACT}

Japanese government planners use the average age of the manufacturing capital stock as one measure of their country's international "competitiveness." Compared to the U.S., the data show that Japanese depreciation rates are higher and that capital stocks a:re younger.

In nuch of economic analysis, higher rates of depreciation are assumed to result in poorer economic performance. A high depreciation rate lowers the net capital stock, and decreases the level of output.

In this paper, we argue that Japan's high depreciation rate is caused by that country's high rate of technological progress. High depreciation rates may be a symptom of a rapidly growing economy.

our results have implications for the international comparison of investment rates. Many economists have compared U.S. and Japanese investment rates net of the depreciation of capital. Presumably, economists are interested in investment rates because of the belief that high rates are positively correlated with a high level of economic performance.

If technological progress causes depreciation rates to be high, however, net investment rates may not be informative about a nation's welfare. Two countries with the same net investment rate can have different rates of per capita output growth if their rates of technological progress are different. We show that the investment rate gross of depreciation may be a better indicator of welfare. 


\title{
Technological Progress and Endogenous Capital Depreciation: Evidence from the U.S. and Japan
}

\author{
Robert Dekle $e^{1}$
}

I. Introduction.

In this paper, we will examine how depreciation and scrapping rates change when a country's rate of technological progress changes. In much of economic theory, the rate of capital depreciation is assumed to be fixed. ${ }^{2}$ A high rate of depreciation lowers the net capital stock, and decreases the level of output.

Higher rates of depreciation, however, may not always result in poorer economic performance. If the best technology is embedded in only the latest vintage of capital, a rise in the rate of technological progress may mean that capital is scrapped earlier and that measured depreciation rates are higher. A high rate of depreciation may be a symptom of a country with a high rate of technological progress.

It is well-known that post-war Japan invested in capital of the latest vintages, sometimes imported from the United states or from Europe. For example, the Japanese steel industry became

${ }^{1}$ The author is: Economist in the Division of International Finance, Board of Governors of the Federal Reserve system, and Assistant Professor of Economics and International Relations, Boston University. I thank the very helpful discussions with Sam Kortum, and especially Debraj Ray. All errors are entirely my own. This paper represents the view of the author and should not be interpre:ed as reflecting those of the Board of Governors of the Federal Reserve system or other members of its staff.

${ }^{2}$ An often-used functional form is the exponential rate of depreciation. 


\section{2}

highly efficient by scrapping old equipment and investing in oxygen-consuming open-hearth furnaces (Kosai, 1986). Observers to Japan from the United States in the 1960s were surprised to find Japanese firms demolishing relatively recent entire plants and building brand new factories on the same site. ${ }^{3}$

Japanese government planners use the average age of the manufacturing capital stock as one measure of their coun'ry's international "competitiveness" (Kuninori, 1988). Compared to the U.S., the data show that Japanese depreciation rates are higher and that capital stocks are younger (Table 1).

In this paper, we attempt to simulate using U.S. and Japanese data the negative association between the rate of technological progress and the age of the marginal (oldest) capital stock. We take as the starting point, one of the simplest general equilibrium models that allow for endogenous scrap dates, the Solow, Tobin, von Weizsacker, Yaari (1956) fixed-coefficients vintage capital model.

A well-known feature of the model is that steady-states exist only when technical progress is of the purely labor-saving variety (Solow, et. al., 1966; Inada, 1968). We simulate the steady-state for reasonable American and Japanese parame:er values and find that the rate of labor-augmenting technical progress and the age of the marginal capital stock are,

${ }^{3}$ In 1965, NKK steel scrapped a 5.5 million ton plant built only five years ago, and constructed on the same lot in suburban Tokyo, a 6 million ton ultramodern facility (McCraw and O'Brien, $1986)$. 
surprisingly, positively related. A rise in the rate of technological progress lowers the depreciation rate. Our simulation results are contrary to much of the anecdotal evidence linking high depreciation and scrapping rates with a high rate of technological progress.

Our steady-state results conflict with the empirical evidence because we employ a special type of technical progress, that of Harrod-neutrality. A higher rate of technical progress will raise the net returns to new capital and induce faster scrapping. In the case of purely labor-augmenting technical progress (automation), however, there is an offsetting effect. Automation reduces the labor required to produce a unit of output. With full-employment, the excess labor will have to be absorbed in the earlier vintages, raising the age of the marginal capital stock and lowering the depreciation rate.

For Japan between 1950 and 1970 and for many developing countries today such as Indonesia and China, labor is abundant relative to capital. The literature on induced technical innovation (Hicks, 1932, pp. 124-25; Kennedy, 1964; Phelps and Drandaisis, 1966) argues that technical progress proceeds in the direction to save on the most slowly growing factors. The assump:ion of Harrod-neutral technical progress appears to be too restrictive for Japan during its high growth era. Capitalaugmenting innovations may have occurred.

To allow for capital-augmenting technical progress, we examine paths other than the steady-state. This paper is one of 
the first to simulate transition paths for the vintage capital model for different rates of capital-augmenting technical progress. We find that an increase in the rate of capitalaugmenting technical progress lowers the age of the oldest: capital stock.

At least since Solow (1962), it has been known that vintage capital with fixed coefficients will induce endogenous obsolescence. More recently scott (1991) and Young (1992) have informally argued that depreciation is not due to physical. "wearand-tear", but rather is induced by the appearance of more advanced capital goods. The contribution of our paper is to show that the direction of endogenous capital obsolescence crucially depends on the variety of the technical progress.

This paper is organized as follows. The next section outlines some key features of the Leontief production, emkodied technical progress model of solow et.al. (1966). We show that steady-state balanced-growth paths exist only for the special case when technical progress is purely labor-augmenting.

Section 3 simulates the model for the steady-state for the United states and for Japan. We find, surprisingly, that a higher rate of technical progress will raise the ages of the marginal and average capital stocks and lower the rate of depreciation. In addition, we find new ways of interpreting traditional growth accounting exercises under vintage capital effects. It has been mentioned by stiglitz and Cass (1969) and others that in the presence of vintage capital, the usual solcw 
(1956) procedure for calculating the rate of total factor productivity will induce a specification error. We show that if capital is measured correctly, the specification error is not, at least in theory, serious. Solow residuals can be calculated in the usual way, and the rate of technical progress in the vintagecapital model can be retrieved.

In Section 4, we will first prove that a faster rate of capital-augmenting technical progress in the general path (not necessarily the steady-state) will result in a younger marginal capital stock. We then estimate using Japanese data between 1957 and 1983 that the rate of capital-augmenting technical progress was significantly different from zero. Finally, by performing dynamic simulations, we confirm that along the convergent path, a rise in the rate of capital-augmenting progress lowers the age of the oldest capital stock.

\section{Capital and Labor Augmenting Technical progress in the}

\section{Vintage Capital Model.}

The starting point for our analysis is the famous solow et.al. (1966) vintage capital model, which assumes fixedcoefficient technology with embodied technical progress. ${ }^{4}$ Capital may last forever, but it is generally not used forever, as better, more modern capital displaces it.

${ }^{4}$ The main difference between the solow et. al. (1966) presentation and ours is that we also allow capital of a given vintage to lose productivity at a rate of $\sigma$ due to physical "wearand-teaj:." 
The model is characterized by three equations: The output equation,

$$
Y(t)=\int_{t-m(t)}^{t} \mu(v) I(v) e^{-\sigma(t-v)} d v
$$

and the two resource constraints,

$$
\begin{gathered}
N(t)=\int_{t-m(t)}^{t} \frac{\mu(v)}{\lambda(v)} I(v) d v, \\
S Y(t)=I(t) .
\end{gathered}
$$

$Y(t)$ is gross output at time $t, N(t)$, the total labor supply, $I(v)$ is the level of gross investment of vintage $v, \mu(v)$, the output per year producible with one unit of capital of vintage $v$, $\lambda(v)$, the output per year per man producible on capital of vintage $v, m(t)$ the age of the oldest vintage of capital in use at time $t, \sigma$ the rate at which the productivity of capital $v$ declines, and $\mathbf{s}$ is the exogenously given fixed-rate of saving out of gross income. For simplicity, we assume that households do not optimize when determining their lifetime consumption profiles. 5

Equation (1) says that gross output is equal to the weighted sum of the capital of different vintages, where the w'eight of vintage $\mathrm{v}$ capital is $\mu(\mathrm{v}) \exp (-\delta(t-v))$. If $\mu(v)$ is iricreasing

${ }^{5}$ Calvo (1976). has examined the putty-clay model in an optimizing framework. Unlike in the malleable capital Ramsey model, Calvo could not prove that the optimal plan approaches a steady-state. To our knowledge, the properties of the "clay-clay" model in an optimizing framework have yet to be deve-.oped. 
with $v$, there is capital augmenting technical progress. Because of "wea:-and-tear" and higher maintenance costs, an unit of vintage $v$ capital becomes less productive at the rate of $\sigma .6$

Equation (2) states that the demand for labor equals its supply. Each unit of vintage $v$ capital employs $\mu(v) / \lambda(v)$ units of labor:. Summing over all of the capital vintages in use, we get the demand for labor. Equation (3) is the definition for the gross saving rate.

Differentiating (1) and (2) with respect to $t$ and after some algebra, we get,

$$
\frac{d Y(t) / d t}{Y(t)}=\lambda(t-m(t)) e^{-\sigma m(t)} N(t) \frac{N^{\prime}(t)}{N(t)}+\mu(t)\left(1-\frac{\lambda(t-m(t))}{\lambda(t)} e^{-\sigma m(t)}\right) s .
$$

(4)

Equation (4) is the dynamic and growth accounting equation for the fixed-coefficients vintage capital model. $\lambda(t-m(t)) \exp (-$ $\sigma m(t))$ is the marginal product of labor at time $t, w(t)$. Hiring one more unit of labor will mean that capital that was previously scrapped must be brought back into service, raising output by $\lambda(t-m(t)) \exp (-\sigma m(t))$.

\footnotetext{
${ }^{6}$ Note that $\delta$ does not appear in equation (2). $\sigma$ is distinct from the rate of depreciation by evaporation. If capital evaporated, labor will be released at the rate of $\sigma$, and $\sigma$ will also appear in (2). If capital evaporated at the rate of $\sigma$, the path of $\mathrm{m}(t)$ will not affected. Less productive capital uses less labor, so the productivity loss will not be a reason to scrap capital earlier.

In our set-up, the decline in the productivity of capital does not release labor. An increase in $\sigma$ will mean that to conserve labor, capital will have to be scrapped earlier. For example, through "wear-and-tear," a factory assembly line of a given vintage may become less productive over time, but the number of workers required to operate the assembly line may be the same.
} 
The term before $s$ is the gross quasi-rent of vintage $t$ capital at time, $\rho(t, t)$. The addition of an unit of capital will raise output by $\mu(t)$. To operate this capital, however, labor units must be removed from the oldest vintage of capital, lowering output by $[\mu(t) / \lambda(t)] *(\lambda(t-m(t)) * \exp (-\sigma m(t))$. If newer capital uses less labor $(\lambda(t)>\lambda(t-m(t)))$, there is a net increase in output from this labor reallocation from old to new capital.

Solow et. al. showed that (4) converges to a steady--state when $\lambda(v)=\exp (\lambda v), N(t)=N * \exp (n t)$, and $\mu(v)=\mu(0)$; that iss, technological progress is purely labor augmenting. Inada (1968) has further proved that the only type of technical progress consistent with the steady-state is the purely labor-auginenting variety.

To see this, solve (1) and (2) for $\mu(v)=\mu(0) * \exp (\mu=)$ and $I(v)=I(0) * \exp (g v)$, to get,

$$
N * e^{n t}=\frac{\mu_{0}}{(\mu-\lambda+g)} * I(0) * e^{(\mu-\lambda+g) t}\left(1-e^{-(\mu-\lambda+g) m(t)}\right)
$$

and

$$
Y(t)=\frac{\mu_{0}}{\sigma+\mu+g} * I(0) * e^{(\mu+g) t}\left(1+e^{-(\mu+g+\sigma) m(t)}\right)
$$

From (1)', for $m(t)$ to be constant, $g=n+\lambda-\mu$. Substituting this $g$ into (2)', we get,

$$
Y(t)=\frac{\mu_{0}}{\sigma+\mu+g} * I(0) * e^{(n+\lambda) t}\left(1-e^{-(n+\lambda+0) m(t)}\right)
$$


$Y(t)$ wil.l be growing at $n+\lambda$, which is different from the growth rate of investment. With positive rates of capital-augmenting technical progress, balanced growth paths cannot exist. The investment-output ratio will asymptotically go to zero.

The non-existence of the steady-state under positive rates of capitial augmenting technical progress is unfortunate since a country like Japan has probably recently experienced technical change of the capital "saving" variety. The literature on induced technical progress has argued that technical progress proceed:s in the direction to conserve on the most slowly growing factors (Hicks, 1932, pp.124-25; Kennedy, 1964; Phelps and Drandakis, 1966). Pre-1965 Japan appeared to be capital scarce. In 1965, Japan's capital-output ratio was 1.27 compared to 4.55 in that year for the United states. For Japan, technical change may have proceeded in the direction to conserve on capital.

Kawagoe, otsuka, and Hayami (1986) attempted to measure biases in technical change in agriculture for the United states and for Japan. They found that differences in the patterns of technical change in the two countries were induced by differences in the levels of relative factor prices. The authors conclude that both countries developed agricultural technology in the direction of facilitating the substitution of relatively abundant factors for scarce factors according to market signals. Japan developed technology to conserve on land, the United states on labor. Japan is of course much more densely populated than the United states. 
III. Endogenous capital scrapping and depreciation in the

steady-state: U.S. and Japanese evidence.

In this section, we will simulate the fixed-coefficient

vintage capital model developed in the previous section. We will assume that Japan achieved its steady-state level of $\mathrm{m}$ ar:ound 1976. The U.S. is assumed to have been around its steady--state $\mathrm{m}$ for the entire post-war period. ${ }^{7}$ The previous section showed that $g=\lambda+n$ is a candidate for the growth rate in the balanced growth path when technical progress is purely labor-augmenting.

The section concludes by drawing implications of the vintage capital model for growth accounting.

For $\mu=0$, equation (5) collapses to,

$$
s=\frac{I(t)}{Y(t)}=\frac{\sigma+g}{\mu_{0}\left[1-e^{-(\sigma+g) m}\right]}
$$

The price of a unit of vintage $v$ capital at time $t$ is the present discounted value of future quasi-rents from time $t$ to $\mathrm{v}+\mathrm{m}$,

$$
P(t, v)=\mu_{0} \int_{t}^{v+m}\left[e^{-\sigma(u-v)}-e^{\lambda(u-v-m)} e^{-\sigma m}\right] e^{-r u} d u
$$

where $r$ is the real rate of interest.

${ }^{7}$ Christiano (1989) and Iwamoto (1993) both assume that the U.S. economy has been around its steady-state since World War II. The Japanese economy, in contrast, had a capital-labor ratio of 12 percent of the U.S. value in 1946 (Iwamoto, 1993). Both Christiano (1989) and Iwamoto (1993) model the 1955-1975 period in post-war Japan as an economy in a transition path. Comparing the American and Japanese capital-output ratios over time, Iwamoto (1993) concludes that the Japanese economy has reached close to the steady-state (close to the U.S. capital-output ratio) by the mid1970s. 
The market value of capital is then,

$$
K(t)-\int_{t-m}^{t} P(t, v,) I(0) e^{g v} d v
$$

and the rate of depreciation is defined as the difference between gross and net investment, divided by the level of gross investment.

$$
\omega=\frac{I(t)-\frac{d K(t)}{d t}}{I(t)} .
$$

The simulations adopt the following strategy. We normalize $P(t, t)=1$, and given the values of the other parameters, solve (5)' and (6) simultaneously for $r$ and $m$, subject to the nonnegativity constraint for $r$. The value of $\omega$ is derived from simple substitution.

\section{Dat.a.}

Takle 2 depicts the parameter values used for the simulations. The average annual gross saving and population growth rates are from Summers and Heston (1991). In the steadystate, the rate of labor-augmenting technical progress is equal to the growth in real wages. The average annual growth rate of real wagjes is from the OECD National Accounts, Detailed Tables (various; years).

$\mu(0)$ and $\sigma$ were chosen to satisfy the non-negativity constraint for $r$, and to give plausible results for the average vintage of existing capital. From Kuninori (1984), we know that the average vintages of capital in manufacturing for Japan and 
for the United States are 6.78 and 9.47. For Japan, a J as small as that of the united states would result in a negative $r$. That Japan's $\sigma$ is high may be indicative of the high "wear-and-tear" of Japanese capital equipment. Because of the country's long labor hours, capital is used more intensively, and it may wear faster. 8

\section{The Simulation Results.}

Table 3 shows how the age of the oldest (marginal) capital stock changes when there is a change in the rate of labor augmenting technical progress.

surprisingly a higher rate of technical progress raises the ages of the marginal and average capital stocks. A higher rate of $\lambda$ will increase the steady-state level of gross investment. Given a fixed growth rate of labor, capital will have to be scrapped earlier. For labor-augmenting technical progress, however, the offsetting effect dominates: the amount of labor needed to man each unit of capital falls. With full-employment, the displaced labor will work on the earlier vintages.

The depreciation rate, $\omega$, falls with an increase in $\lambda$. An increase in the quantity of existing capital (m) raises $K(t) / I(t)$, lowering $\omega$. For a given gross saving rate, the fall in $\omega$ raises the net saving rate.

Table 4 depicts how $\mathrm{m}$ and w change with the gros:s saving rate, s. The results for the baseline parameter values are

${ }^{8}$ In 1983, the average working hours for Japanese nonagricultural workers were 40.4 ; for the United State:s, the hours were 35.0 (Prime Minister's office, 1985, p.48). 
underlinied. At the baseline, the average ages of the capital stocks for both countries closely match the values in Table 1.

A rise in s raises the quantity of new capital and labor will be transferred from the old capital to the new, lowering $\mathrm{m}$. The depreciation rate, however, falls. A high $s$ lowers $r$, the real interest rate, raising the price of an unit of capital. Although there are fewer physical units of capital, each unit has a higher price, raising the market value of capital, $k(t)$, and lowering $\omega$.

Implications for Growth Accounting.

Suppose that a researcher tries to measure total factor productivity (the solow residual) the usual way when production in the actual economy is fixed-coefficients with Harrod-neutral technical progress. What is the bias, if any, in using the normal solow residual as an estimate for the rate of technical progress?

setting $\mu(t)=1$, in the steady-state, (4) becomes,

$$
\frac{d Y(t) / d t}{Y(t)}-\beta * n+\rho(t, t) * s
$$

where $B$ is the labor-share of output and $\rho(t, t)$ is the quasi-rent of vintage $t$ capital at time $t$. (4)' ' is the growth accounting equation for the fixed-coefficients vintage capital model in the steady-state.

The Solow residual is usually calculated as,

$$
\frac{d Y(t) / d t}{Y(t)}-\beta * n-(1-\beta) * \frac{d K(t) / d t}{K(t)}
$$


Stiglitz and Cass (1969) argue that in the presence of vintage capital effects, the usual solow (1956) procedure for calculating the rate of total factor productivity growth induces a specification error.

From (9), we can see that a specification error does not exist when $(d K(t) / d t) / K(t)$ is defined as the growth rate of the market value of the capital stock.

In our vintage capital model, the steady-state growth rate of both output and the market value of capital is $g=\lambda+n$. Substituting $g$ for $(d Y(t) / d t) / Y(t)$ and $(d K(t) / d t) / K(t)$ in (9) and simplifying, the estimated solow residual is $\beta * \lambda$. Given estimates of the labor share of gross output, $B$, and the growth rates of both labor and the market value of capital, we can retrieve the rate of labor-augmenting technical progress from the usual growth accounting methods.

Examples with Japanese and U.S. Data.

Below, Solow residuals are estimated using Japanese and U.S. data on the growth rates of capital and labor. As a measure of the growth rate of the market value of capital, we use the average annual growth rate of household net financial assets. 9

To capture the steady-state, the Japanese and U.S. data are time-averaged between 1976 and 1988 and 1955 and 1988, respectively. For the labor share of gross output, we use 0.70 for Japan and 0.67 for the United States (Bernard and Jones,

9Japanese household balance sheets are from EPA(1992). American household balance sheets are from the Federal Reserve Board (1990). 
1993). All values are real.

Jạpanese Data.

Between 1975 and 1988, the average annual growth rate of the market value of capital was 0.088 . We know that the average annual growth rates of gross output and labor in this period were 0.041 and 0.007 . Substituting these values into the usual growth account:ing equation (9), total factor productivity (the solow residuall) is estimated as $0.70 * 0.014$.

We showed above that the solow residual divided by the labor share should give us a measure of the rate of labor-augmenting technical progress in the vintage capital model. Using Japanese data, the rate of Harrod-neutral technical progress in the vintage capital model $(0.034)$ is underestimated by the usual Solow procedure $(0.014)$.

\section{U.S. Data.}

Between 1955 and 1988, the average annual growth rate of the market value of capital was $0.070 ;$ the average annual growth rates of real gross output and labor were 0.031 and 0.012 . Total factor productivity is calculated as $0.68 * 0.00018$ (from eq.(9)) .

Acjain, the rate of Harrod-neutral technical progress in the vintage capital model $(0.019)$ is underestimated by the usual Solow method $(0.00018)$.

For both countries, unlike what the theory predicts, the usual growth accounting techniques give misleadingly low estimates of the rate of technical progress when the growth rate of the market value of capital is used. This is because the 
market value of capital in the data grows much faster than the values derived from the simulations.

one reason for the very rapid growth in the observed market values of capital may be the equity premium (Mehra and Prescott, 1985). With uncertainty, the average increase in the market value of capital in the data will include a premium that is absent in our certainty model.

This section has shown that in the steady-state, the U.S.Japan differences in the capital vintages and in the depreciation rates cannot be explained by differences in $\lambda$. We were able to calibrate the benchmark m's for both countries by raising Japan's gross saving rate and $\sigma$. To achieve an inverse association between the rate of technical progress and the age of the marginal capital stock, we must drop the assumption of purely labor-augmenting technical progress. To do this, we must examine paths other than the steady-state.

IV. Capital Augmenting Technical Progress in the Transition Path.

In this section, we will first prove that a faster rate of capital-augmenting technical progress in the general path will result in a younger marginal capital stock. We then show that for Japanese data, the rate of capital-augmenting tecrnical progress, $\mu$, along the convergent path was significantily different from zero at 8.6 percent per year.

We use this estimated $\mu$ to benchmark the Japanese economy's 
convergent path between 1957 to 1975. Performing dynamic simulations, we confirm that a rise in $\mu$ lowers $m$, the age of the oldest capital stock. A rise in $\lambda$ increases $m$ along the convergent path.

Capital augmenting technical progress and scrapping.

Assume that two economies, $A$ and $A^{\prime}$, are the same in all respe:cts, except that $\mu^{\prime}(t)>\mu(t)$ for all $t$. Assume that $\lambda(t)$ behaves so that $\mu^{\prime}(t) / \lambda(t)$ and $\mu(t) / \lambda(t)$ are non-increasing in $t$. Also, assume that initially, $Y^{\prime}(\tau)>Y(\tau)$ for $0<=\tau<=T$.

We wish to prove that, $m^{\prime}(T)<m(T)$.

\section{Proof by contradiction:}

Assume to the contrary that, $t-m(T)>=t-m^{\prime}(T)$.

Since initially $I^{\prime}(\tau)>I(\tau)$, if $t$ is "large" enough, we can discard enough $I^{\prime}(\tau)$ to mimic the $I(\tau)$ path.

Then,

$$
Y^{\prime}(T)=\int_{t-m(T)}^{T} \mu^{\prime}(v) I(v) d V>Y(T)
$$

and $I^{\prime}(T)$ is greater than $I(T)$.

We can increase $T$, repeat the argument, and show that $I^{\prime}(\mathrm{T})>I(T)$ for all $\mathrm{T}$.

Then, given,

$$
N(T)=\int_{T-m^{\prime}(T)}^{T} \frac{\mu^{\prime}(v)}{\lambda(v)} I^{\prime}(v) d v=\int_{T-m(T)}^{T} \frac{\mu(v)}{\lambda(v)} I(v) d v
$$


$\mathrm{m}^{\prime}(\mathrm{T})<\mathrm{m}(\mathrm{T})$, which is a contradiction.

The above proof shows that along any path, a higher rate of capital-augmenting technical progress will lead to a youriger capital stock. This is verified for the convergent path in the numerical simulations in section 4.3 .

Estimation of the rate of capital augmenting technic:al progress for Japan.

Assume that $\lambda(t)=\exp (\lambda t)$. Let $g(t)=Y(t) / \exp \left(-(\lambda+n) t_{0}\right)$, or output per efficiency units of labor. Using the definitions for $\mathrm{s}$ and $\mathrm{n}$, we can rewrite (4) as,

$$
\frac{g^{\prime}(t)}{g(t)}=(s \mu(t)-\lambda-n)-\left(s \mu(t)-\frac{n}{g(t)}\right) * e^{-\lambda * m(t)} * e^{-\sigma * m(t)}
$$

From equations (1)', (2)', and (3), if $\mu(t)$ approaches $\mu(0)$ asymptotically, it can be shown that in the steady-state,

$$
\begin{gathered}
m *=-\frac{1}{\sigma+\lambda+n} \log \frac{s \mu_{0}-\sigma-n-\lambda}{s \mu_{0}}, \\
g *=\frac{n}{\mu_{0} s\left(1-e^{-n m *}\right)}
\end{gathered}
$$

Plugging-in the values for Japan from Table 2, we get $g *=0.432$ and $m *=14.21$

Transforming (4)' with the help of (10) and (11),

$$
\frac{g^{\prime}(t)}{g(t)}=s \mu(t) e^{-(\lambda+\sigma) m^{*}}\left(1-\frac{n}{s \mu_{0} g^{*}}\right)-e^{-(\lambda+\alpha) m(t)}\left(1-\frac{n}{s \mu(t) g(t)}\right)
$$


Japan in the early 1950s had output below the steady-state, $g *(t)<=g(t)$, and whatever capital stock remained after the World war II bombing was older than today's, $m(t)>m *$. Then (12) implie:s that $g^{\prime}(t)>=0$.

Ass mentioned, Solow, et.al. showed that (12) (or 4) converges to an unique steady state (10) and (11), when $\mu(t)$ is a constant. Here we parameterize $\mu(t)$ as $\mu(0)(1-\exp (-\mu t))$ so that in the steady-state, if $\mu>0, \mu(t)=\mu(0)$.

Differentiating equation (2) with respect to time, rearranging, and using the above notation for $g(t)$, we get,

$$
m^{\prime}(t)=1+e^{\lambda(t-m(t))} e^{-o m(t)} n e^{n t} Z-\mu(t) e^{-\lambda m(t)} s g(t) e^{(\lambda+n) t} Z,
$$

where,

$$
Z=\left[\mu(t-m(t)) s g(t-m(t)) e^{(\lambda+n)(t-m(t))}\right]^{-1} .
$$

Equation (13) is intractable for estimation jointly with (12). For estimation, we will approximate $m(t)$ by $m$ * (1+exp ($k t))$. As $t$ increases, $m(t)$ approaches $m * .{ }^{10}$

For more efficient estimation, we exploit the expression for the marginal product of labor, and estimate

$$
\frac{W(t)}{e^{\lambda t}}=e^{-(\lambda+\sigma) m *\left(1+e^{-k t}\right)}
$$

${ }^{10}$ In the simulations in the next subsection, the two differential equations (12) and (13) will be numerically solved for
the $g(t)$ and $m(t)$ paths. 
jointly with equation (12) by non-linear least squares. For both equations, we assume additive errors caused by the mismeasurement of the dependent variables. All parameters other than $\mathrm{k}$ and $\mu$ are set at their steady-state benchmark values depicted in Tables 2 and 4 .

\section{Data.}

To estimate (12) and (14) on annual data between 1957 and 1988, we need a trend term, and data on wages and full employment output, $Y(t)$. We obtain wages by dividing aggregate wage payments (Economic Planning Agency (EPA), various years) by the total number of workers (Prime Minister's office, various years). Raw GNP is from EPA (various years). Since $Y(t)$ in the moclel is at full-employment, we calculate the Japanese natural rate of output by the method of Nelson (1989). ${ }^{11}$

Table 5 depicts the raw data $g^{\prime}(t) / g(t)$, in percent, and $w(t) / \exp (\lambda t)$, in millions of 1980 yen. Although fluctuating, the growth rate of $g(t)$ declines over time; by the late 1980s, the growth rate is close to zero. Wages per efficiency units of labor reach their maximum of a million yen per year by the mid 1970s. These data provide further evidence that Japan approached its steady-state by the mid-1970s.

\section{Results.}

Table 6 shows the non-linear least squares estimates of $\mathrm{k}$ and $\mu$. The second column displays the results when an AR(1)

${ }^{11}$ Nelson's (1989) procedure allows us to make inferences about movements in the natural level of real GNP by the relative fluctuations of the price level and actual real GNP. 
process is assumed for the error terms.

We find in both columns that $\mu$ is significantly different from zero. With $\mu 0.086$, by $1975, \mu(t)$ is equal to 79 percent of its steady-state value of $\mu(0)$.

\section{Simulation of the Convergent Path.}

In this subsection, we trace the convergent paths for $g(t)$ and $m(t)$ by solving the differential equations (12) and (13) simultaneously. We assume as before that $\mu(t)$ is $\mu(0)(1-\exp (-$ $\mu t)$ ) where $\mu=0.086$ as estimated. ${ }^{12}$

We choose 1957 as the starting date. In $1957, g(t)$ in the data was 0.18 . We pick an initial $m(t)$ so that the economy wili converge to the steady-state values of $g *(0.418)$ and $m *(14.21$; in akout 18 years (1957-1975).

The boxed lines in Figures 1 and 2 plot the results of the simulations for $m(t)$. $m(t)$ drops very rapidly in the first decacle and then gradually converges to its steady-state value.

We next perform comparative dynamics exercises. We raise $\lambda(t)$ and $\mu(t)$ and examine what happens to $m(t)$ along the convergent path.

As before, a rise in $\lambda(t)$ raises $m *$ (Figure 1 ). This increase tilts the entire $m(t)$ profile upwards. The rate of scrapping slows along the entire convergent path.

In sharp contrast, along the convergent path, an increase in $\mu(t)$ lowers $m(t)$; scrapping occurs sooner (Figure 2). Newer

\footnotetext{
${ }^{12}$ The fourth-order Runge-Kutter algorithm (in Mathcad) is used to solve (12) and (13).
} 
capital is more productive so firms allocate labor to the latest capital vintages. Unlike in the case when $\lambda(t)$ rises, when $\mu(t)$ increases, newer capital does not require less labor. Technical progress therefore induces a net re-allocation of labor from old to new capital.

IV. Conclusion.

This paper has shown that the bias in technical progress crucially affects the sign of the relationship between the rates of technical progress and capital scrapping. If technical progress is of the capital-augmenting variety, then a rise in the rate of technical progress will raise the rate of scrapping, making the capital stock younger.

our results have implications for international comparisons of investment rates. For example, most authors (Hayashi, 1986; Horioka, 1990; Dekle, 1993) have compared U.S. and Japanesie investment rates net of the depreciation of capital. Presumably, economists are interested in investment rates because of the belief that high rates are positively correlated with a high level of economic performance.

If technological progress causes depreciation rates to be high, however, net investment rates may not be informative about a nation's welfare. Two countries with the same net investment rate can have different rates of per capita output growth if their rates of technological progress are different.

The investment rate gross of depreciation may be a ketter indicator of welfare. 


\section{Table 1}

\section{Depreciation Rates and the Average Age of the Capital stock \\ (U.S. and Japan)}

Depreciation/Gross Investment

1970

1975

1980

1985

1989
U.S.

0.345

0.411

0.387

0.399

0.428
Japan

0.373

0.513

0.551

0.605

0.593

Source: Hayashi (1991).

1970

1975

1980

1984
Average Age of the Capital stock

U.S.

9.8

9.6

14.2

10.1
4.9

5.7

9.1

6.9
Japan

Source: Kuninori (1984). 
Table 2

(Initial Parameter Values)

\section{Japan \\ (Annual Average, 1976-1988)}

$\begin{array}{lcc}\begin{array}{l}\text { Population } \\ \text { Growth } \\ \text { Rate }\end{array} & 0.007 & 0.012 \\ \begin{array}{l}\text { Wage } \\ \text { Growth } \\ \text { Rate }\end{array} & 0.034 & 0.019 \\ \begin{array}{l}\text { Gross Saving } \\ \text { Rate }\end{array} & 0.38 & 0.24 \\ \mu(0) & 0.45 & 0.45 \\ \begin{array}{l}\sigma \\ \text { Mource: Population growth rate, and Gross Saving Rate, Summers and } \\ \text { Heston (1991). Wage Growth Rate, OECD National Account:s, Detailed } \\ \text { Tables. }\end{array} & 0.11 & 0.055 \\ \end{array}$

U.S. (Annual Average, 1955-1988) 
Table 3

Changes in the Rate of Labor-Augmenting Technical Progress.

Steady-state Simulation Results for the U.S.

Labor-augment.

Tech. F'rog.
Net Saving

Rate

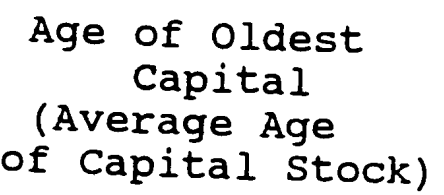

14.61

(7.07)

18.82

(8.47)

23.55

(9.86)
Depreciation

Rate (Dep/I)
0.010
0.021
0.020
0.025
0.030
0.032

*Gross saving rate fixed at the baseline value of 0.24 .

\section{Steady-state Simulation Results for Japan}

$\begin{array}{cccc}\begin{array}{c}\text { Labor-augment. } \\ \text { Tech. Prog. }\end{array} & \begin{array}{c}\text { Net Saving } \\ \text { Rate }\end{array} & \begin{array}{c}\text { Age of oldest } \\ \text { Capital } \\ \text { (Average Age } \\ \text { of Capital Stock) }\end{array} & \begin{array}{c}\text { Depreciation } \\ \text { Rate (Dep/I) }\end{array} \\ 0.01 .0 & 0.029 & \begin{array}{l}10.69 \\ (5.18)\end{array} & 0.952 \\ 0.020 & 0.037 & \begin{array}{l}11.79 \\ (5.58)\end{array} & 0.938 \\ 0.030 & 0.047 & \begin{array}{l}13.36 \\ (6.13)\end{array} & 0.919 \\ 0.040 & 0.061 & \begin{array}{l}15.94 \\ (6.98)\end{array} & 0.894\end{array}$

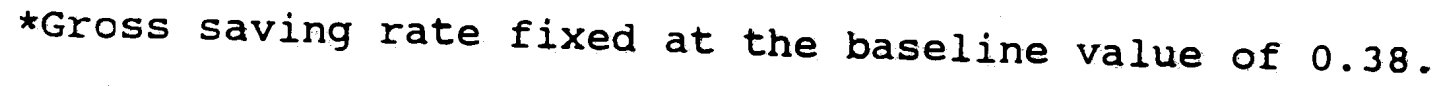


Table 4

Changes in Gross Saving Rates.

Steady-state simulation Results for the U.S.

\begin{tabular}{|c|c|c|c|}
\hline $\begin{array}{c}\text { Gross Saving } \\
\text { Rate }\end{array}$ & $\begin{array}{l}\text { Net Saving } \\
\text { Rate }\end{array}$ & $\begin{array}{c}\text { Age of oldest } \\
\text { Capital } \\
\text { (Average Age } \\
\text { of Capital Stock) }\end{array}$ & $\begin{array}{l}\text { Depreciation } \\
\text { Rate (Dep/I) }\end{array}$ \\
\hline 0.20 & 0.017 & $\begin{array}{c}36.20 \\
(14.78)\end{array}$ & 0.931 \\
\hline 0.22 & 0.021 & $\begin{array}{c}23.61 \\
(10.38)\end{array}$ & 0.924 \\
\hline 0.24 & 0.025 & $\frac{18.50}{(9.37)}$ & 0.919 \\
\hline 0.26 & 0.029 & $\begin{array}{l}15.44 \\
(7.10)\end{array}$ & 0.915 \\
\hline
\end{tabular}
0.019 .

*Labor-augmenting technical progress fixed at the baseline value of *Results for the baseline gross saving rate of 0.24 are underlined.

Steady-state simulation Results for Japan

\begin{tabular}{|c|c|c|c|}
\hline $\begin{array}{c}\text { Gross Saving } \\
\text { Rate }\end{array}$ & $\begin{array}{l}\text { Net Saving } \\
\text { Rate }\end{array}$ & $\begin{array}{c}\text { Age of oldest } \\
\text { Capital } \\
\text { (Average Age }\end{array}$ & $\begin{array}{l}\text { Depreciation } \\
\text { Rate (Dep/I) }\end{array}$ \\
\hline
\end{tabular}
0.34
0.042
28.72
0.952
$\underline{0.38}$
0.052
(11.61)
14.21
$(6.42)$
0.42
0.062
10.62
(4.93)
0.46
0.072
8.66
(4.07)
$\underline{0.938}$
0.919
0.894

tLabor-augmenting technical progress fixed at the baseline value 0.034.

tResults for the baseline gross saving rate of 0.38 are underlined. 
Table 6

Joint Estimation of Equations (12) and (14)

With Data in Table 5

$$
\text { Non-linear Least Squares }
$$

k

$$
0.019
$$

(11.86)

0.086
Generalized Method of Moments with $\mathrm{AR}(1)$ Correction
(9.13)

Log-likelihood:

61.56

$\mu$

t-statistics in parentheses. Number of Observations: 32 .
0.019

(1.94)

0.086

(2.09) 
Table 5

Data Used for Estimation

\begin{tabular}{|c|c|c|}
\hline & $w(t) / \exp (\lambda t)$ & $g^{\prime}(t) / g(t)$ \\
\hline 1957 & 0.39574 & 0.020974 \\
\hline 1958 & 0.41920 & 0.094773 \\
\hline 1959 & 0.43466 & -0.026744 \\
\hline 1960 & 0.45027 & 0.053486 \\
\hline 1961 & 0.47500 & 0.063920 \\
\hline 1962 & 0.52058 & 0.12004 \\
\hline 1963 & 0.54791 & -0.0034488 \\
\hline 1964 & 0.58236 & 0.065329 \\
\hline 1965 & 0.61289 & 0.062364 \\
\hline 1966 & 0.63241 & 0.012661 \\
\hline 1967 & 0.65942 & 0.067066 \\
\hline 1968 & 0.69948 & 0.076161 \\
\hline 1969 & 0.75506 & 0.072997 \\
\hline 1970 & 0.82255 & 0.066884 \\
\hline 1971 & 0.87967 & 0.057799 \\
\hline 1972 & 0.93276 & -0.010133 \\
\hline 1973 & 0.96343 & -0.031997 \\
\hline 1974 & 0.99855 & -0.025367 \\
\hline 1975 & 1.03850 & 0.069835 \\
\hline 1976 & 1.04758 & -0.016708 \\
\hline 1977 & 1.04321 & 0.022906 \\
\hline 1978 & 1.02236 & 0.020355 \\
\hline 1979 & 1.03142 & 0.027972 \\
\hline 1980 & 1.02580 & -0.0096149 \\
\hline 1981 & 1.03078 & 0.018433 \\
\hline 1982 & 1.02522 & 0.00023992 \\
\hline 1983 & 1.01254 & 0.0011307 \\
\hline 1984 & 1.00826 & -0.013997 \\
\hline 1985 & 0.99972 & 0.0088593 \\
\hline 1986 & 0.98356 & 0.0030270 \\
\hline 1987 & 0.98546 & 0.0032080 \\
\hline 1988 & 0.99742 & 0.0015742 \\
\hline & See $\mathrm{TC}$ & \\
\hline
\end{tabular}




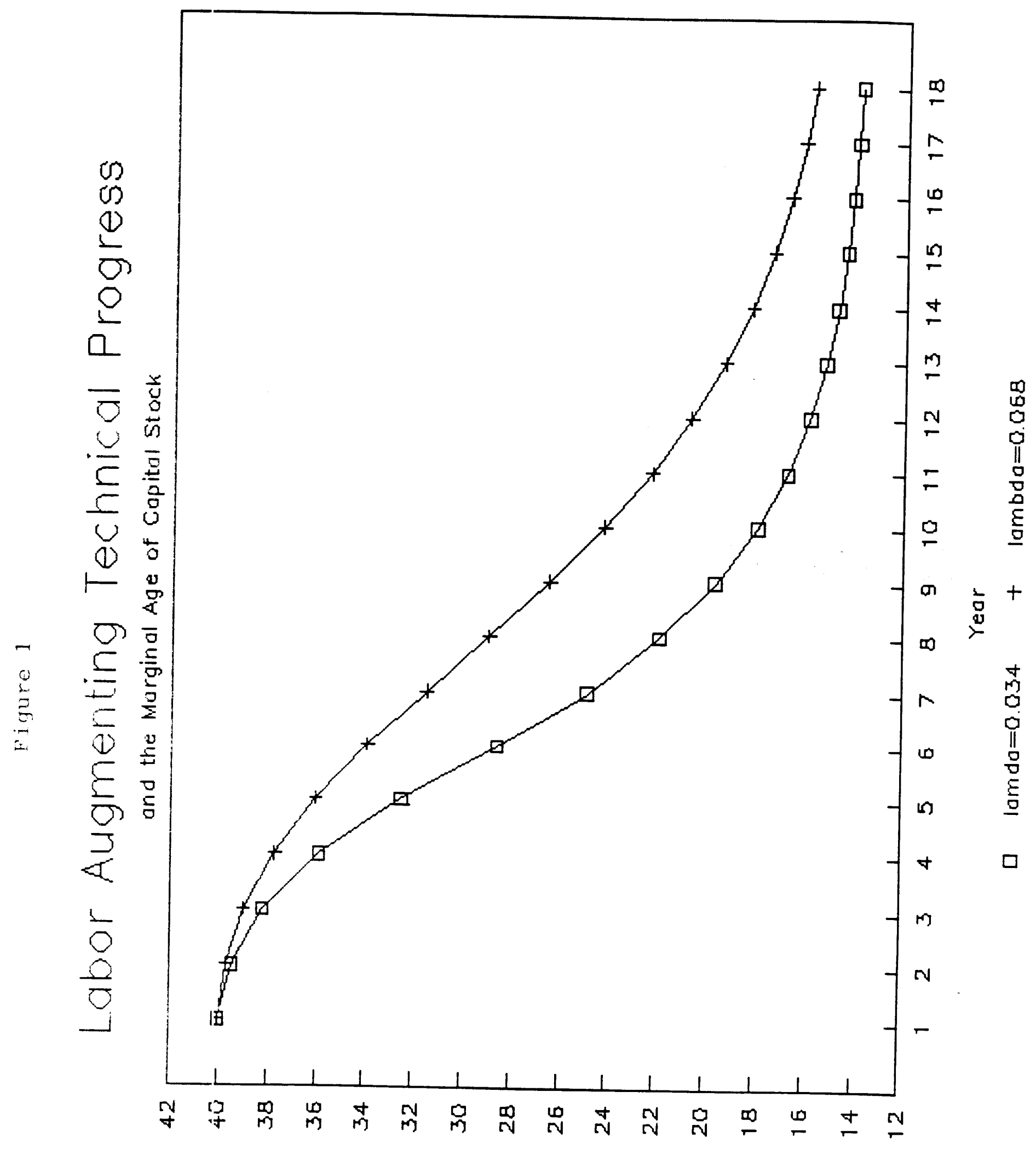




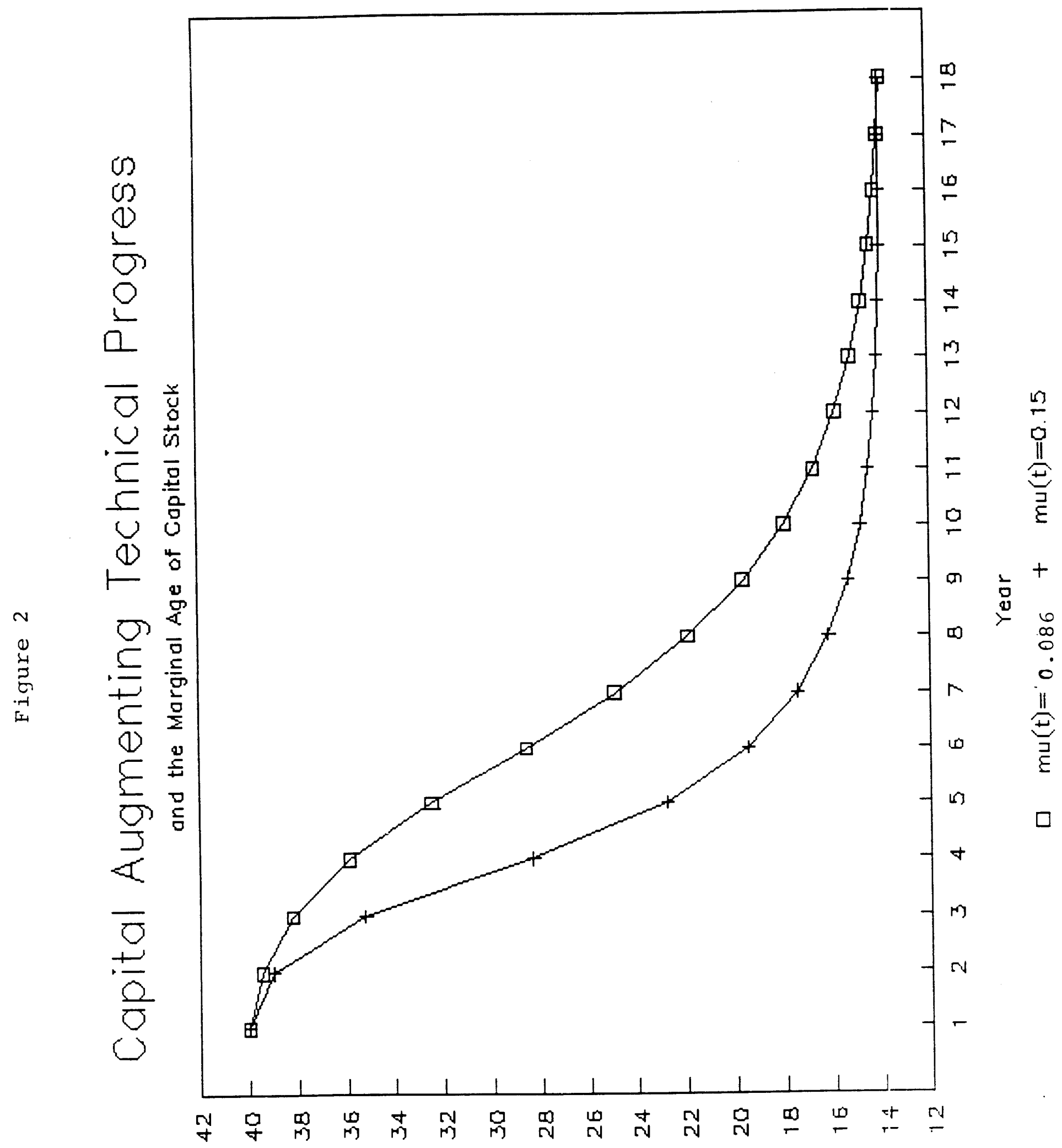


Refererces.

Bureau of Economic Analysis, Department of Commerce (1990). "siurvey of Current Business," October.

Bernard, A. and C. Jones (1993). "Comparing Apples to Oranges: Productivity Convergence and Measurement Across Industries and Countries," mimeographed, MIT. Calvo, G. (1976). "optimal Growth in a Putty-clay Model,"
Econometrica. Christiano, L. (1989). "Understanding Japan's Saving Rate: The
Reconstruction Hypothesis,' Federal Reserve Bank of Minneapolis Quarterly Review.

Dekle, R. (1993). "Raising Saving Rates: Lessons from the Japanese Experience." manuscript, Boston University.

Economic Planning Agency, Government of Japan (1992) - Annual Report on the National Accounts.

Federal Reserve Board (1990). Balance Sheets for the U.S. Economy. 1949-88.

Hayashi, F. (1986). "Why is Japan's Saving Rate so Apparently
(1) Olivier Blanchard and Stanley Fischer, ed. NBER High?," in olivier Blanchard and stanley Fischer, ed. NBER Macroeconomic Annual.

Hayashi, F. (1991). "Rejoinder to Dekle and Summers," Bank of Japan Nionetary and Economic Studies.

Hicks, J.R. (1932) The Theory of Wages. Macmillan. Horiok:a, C. (1990). "Why is Japan's Household Saving Rate So High?
A Literature Survey," Journal of Japanese and International Economies.

Iwamot:o, Y. (1993). "Does the Dynasty View Help to Explain Japan's High Saving Rate?", manuscript, Kyoto University and Boston University.

Kawagise, T., K. otsuka, and Y. Hayami (1986). "Induced Bias of 'Technical Change in Agriculture: The United states and Japan, 1880-1980, Journal of Political Economy.

Kennedy, C. (1964) "Induced Bias in Innovation and the Theory of Distribution," Economic Journal. Kosai, Y. (1986). The Era of High-Speed Growth: Notes on the
Postwar Japanese Economy, Tokyo University Press. 
Kuninori, M. (1984). "On Equipment Vintages," Setsubi Vintage ni Tsuite, Japan Development Bank Working Paper.

Kuninori, M. (1988). "On Equipment Depreciation Rates," Setsubi no Shokyaku Ritsu ni Tsuite, Japan Development Bank Working Paper.

Inada, K. (1968). "Fixed Factor Coefficients and Harrod-neutral Technical Progress," Review of Economic studies.

Mccraw, T. and N. O'Brien (1986). "Production and Distribution: Competition Policy and Industry Structure," in McCraw (ed.) America versus Japan, Harvard University Press.

Mehra, R. and E. Prescott (1985) " "The Equity Premium: A Puzzle," Journal of Monetary Economics.

Nelson, C. (1989). "Implicit Estimates of the Natural and Cyclical Components of Japan's Real GNP," Bank of Japan Monetary and Economic Studies.

OECD (various issues). National Accounts, Detailed Table:j.

Prime Minister's office (various issues). Japan Statistical Annual.

Phelps, E. and E. Drandakis (1966). "A Model of Induced Innovation, Growth, and Distribution,' Economic Journal.

Prime Minister's Office, Government of Japan (1985). International Comparative statistics (Kokusai Tokei Yoran).

Scott, F.G. (1989). A New View of Economic Growth. Clarenclon Press.

Solow, R. (1956). "Technical Change and the Aggregate F'roduction Function," Review of Economics and statistics.

Solow, R. (1962). "Substitution and Fixed Proportions in the Theory of Capital." Review of Economic Studies.

Solow, R., Tobin, J., Von Weizacker, CC., and M. Yaari (1966), "Neoclassical Growth with Fixed-Factor Proportions," Review of Economic Studies. Stiglitz, J. and David Cass (1969). "The Implications of
Alternative Saving and Expectations Hypothesis for Choices of Technique and Patterns of Growth," Journal of Political Economy.

Summers, R. and A. Heston (1991). "A New Internationally Comparable Data Set," Quarterly Journal of Economics.

Takayama, N. (1992). The Greying of Japan: An Economic Ferspective 
on Public Pensions. Kinokuniya.

Takenaka, H. (1993). The Internationalization of the Japanese Economy and Corporate Investment. (Nihon-keizai no Kokusai-ka to Kigyo-Toshi) Tokyo: Hyoron-sha.

Young, A. (1992). "A Tale of Two Cities: Factor Accumulation and Technical Change in Hong Kong and Singapore," manuscript, Massachusetts Institute of Technology. 


\section{International Finance Discussion Papers}

IFDP

Number

485

484

483

482

481

480

479

478

477

476

475

474

473
Titles

1994

Technological Progress and Endogenous Capital

Depreciation: Evidence from the U.S. and Japan

Are Banks Market Timers or Market Makers?

Explaining Foreign Exchange Trading Profits

Constant Returns and Small Markups in U.S.

Manufacturing

The Real Exchange Rate and Fiscal Policy During the Gold Standard Period: Evidence from the United States and Great Britain

The Debt Crisis: Lessons of the 1980s for the $1990 \mathrm{~s}$

Who Will Join EMU? Impact of the Maastricht Convergence Criteria on Economic Policy Choice and Performance

Determinants of the 1991-93 Japanese Recession: Evidence from a Structural Model of the Japanese Economy

On Risk, Rational Expectations, and Efficient Asset Markets

Finance and Growth: A Synthesis and Interpretation of the Evidence

Trade Barriers and Trade Flows Across Countries and Industries

The Constancy of Illusions or the Illusion of Constancies: Income and Price Elasticities for U.S. Imports, 1890-1992

The Dollar as an Official Reserve Currency under EMU

Inflation Targeting in the 1990s: The Experiences

of New Zealand, Canada, and the United Kingdom
Author(s)

Robert Dekle

John Ammer

Allan D. Brunner

Susanto Basu

John G. Fernald

Graciela L. Kaminsky

Michael Klein

Graciela L. Kaminsky

Alfredo Pereira

R. Sean Craig

Allan D. Brunner

Steven B. Kamin

Guy V.G. Stevens

Dara Akbarian

Alexander Cialetovic

Jong-Wha Lee

Phillip Swaggel

Jaime Marquez

Michael P. l_eahy

John Ammer

Richard T. Freeman

Please address requests for copies to International Finance Discussion Papers, Division of International Finance, Stop 24, Board of Governors of the Federal Reserve System, Washington, D.C. 20551. 


\section{International Finance Discussion Papers}

IFDP

Number

472

471

470

469

468

467

466

465

464

462 $\underline{\text { Titles }}$

Author(s)

$\underline{1994}$

International Capital Mobility in the 1990s

Maurice Obstfeld

Prakash Loungani Mark Rush

William L. Helkie David H. Howard Jaime Marquez

Karen H. Johnson

International Dimension of European Monetary Union Implications For The Dollar

European Monetary Arrangements: Implications for the Dollar, Exchange Rate Variability and Credibility

Fiscal Policy Coordination and Flexibility Under European Monetary Union: Implications for Macroeconomic Stabilization

The Federal Funds Rate and the Implementation of Monetary Policy: Estimating the Federal Reserve's Reaction Function

Understanding the Empirical Literature on Purchasing Power Parity: The Post-Bretton Woods Era

Inflation, Inflation Risk, and Stock Returns

Are Apparent Productive Spillovers a Figment of Specification Error?

When do long-run identifying restrictions give reliable results?

$\underline{1993}$

Fluctuating Confidence and Stock-Market Returns

Dollarization in Argentina

Alexander David

Steven B. Kamin

Neil R. Ericsson

Phillip Swagel 